\title{
Energy and nitrogen metabolism of lactating rabbits
}

\author{
By G. G. PARTRIDGE, M. F. FULLER AND J. D. PULLAR \\ Rowett Research Institute, Bucksburn, Aberdeen AB2 $9 S B$
}

(Received 17 May 1982 - Accepted 4 January 1983)

1. Twelve crossbred does (New Zealand White $\times$ California) were offered a diet of high protein and metabolizable energy content $(249 \mathrm{~g} / \mathrm{kg}$ dry matter (DM) and $13.6 \mathrm{MJ} / \mathrm{kg}$ DM respectively) throughout a $32 \mathrm{~d}$ lactation at one of four feeding levels $(240,280,320$ or $360 \mathrm{~g} / \mathrm{d})$. Each feeding level was replicated three times.

2. Milk output was measured by weighing the does before and after their one daily suckling period.

3. The lactation was divided into four consecutive 8-d periods. Each doe was placed in a direct calorimeter for $48 \mathrm{~h}$ around the mid-point of each of these periods and measurements of energy exchange were made. Nitrogen balance was also measured throughout the study period.

4. Milk samples were taken from a parallel group of animals and the estimates of milk composition were applied to the main group of does.

5. From the second period of lactation onwards nearly all does mobilized body tissue to support milk energy secretion, although there was no loss of weight. Multiple regression analyses were used to examine the apparent efficiency with which metabolizable energy and body-tissue energy were utilized for milk production. Overall, the relationship was described by the equation:

$\begin{array}{cccc}\begin{array}{c}\text { Period of lactation ... } \\ \text { Milk E }= \\ \text { 0.735 ME intake - 0.938 Body ER }\end{array} & -296 & 3 & 4 \\ \text { (SE 0.020) } & \text { (SE 0.039) }\end{array}$

where Milk $\mathrm{E}$ is the milk energy output, ME intake is the metabolizable energy intake and Body ER is the body energy retention, all expressed in $\mathrm{kJ} / \mathrm{kg}$ body-weight ${ }^{0.75}$ per $\mathrm{d}$.

All does appeared to be in positive $\mathbf{N}$ balance throughout lactation on this high-protein diet.

There have been several investigations into energy utilization in lactation in the dairy cow and other ruminant species. Such studies have two major aims. The first is to estimate the proportion of nutrient intake used for milk secretion and for body tissue accretion and the extent to which body tissues may be broken down to provide additional nutrients for lactation. The second aim is to estimate the efficiency with which each of these transformations is performed (e.g. Van Es \& Nijkamp, 1967; Flatt \& Moe, 1970). The logistical problems of working with lactating animals while simultaneously measuring energy exchanges by calorimetry have resulted in most research efforts being confined to the dairy cow, with very little information being available for lactating non-ruminant species.

The nutritional requirements of the rabbit have been found generally to be akin to those of other single-stomached species and the animal has ready-made biological advantages for studies on lactation. The doe's normal suckling behaviour involves a short period (approximately $5 \mathrm{~min}$ ) once daily: virtually uninterrupted calorimetry is therefore possible. Information on the efficiency of lactation processes in the rabbit is also fundamental to a description of its nutritional requirements which have been defined more precisely over the last decade as interest has grown in its potential as a meat-producing species. The present study reports observations made by direct calorimetry on the energy exchanges of does during lactation. 
Table 1. Diet composition and chemical analysis $(\mathrm{g} / \mathrm{kg})$

\begin{tabular}{lc}
\hline \hline & 399 \\
Soya-bean meal & 275 \\
Ground oats & 150 \\
Grass meal & 50 \\
Sucrose & 50 \\
Maize oil & 25 \\
Vitamin mix & 50 \\
Mineral mix* & 0.05 \\
D- $\alpha$-tocopherol (antioxidant) & 1.25 \\
Coccidiostat† & \\
Analysis (g/kg DM) $\ddagger$ & 249 \\
Crude protein (nitrogen $\times 6.25)$ & 74 \\
Ash & 148 \\
Acid-detergent fibre & 18.67 \\
\hline
\end{tabular}

DM, dry matter.

* For details, see Partridge \& Allen (1982).

+ Embazin; May \& Baker, Dagenham, Essex.

$¥$ DM content of the diet was $892 \mathrm{~g} / \mathrm{kg}$.

\section{MATERIAL AND METHODS}

Diets

During pregnancy a standard pelleted diet based on weatings, grass meal, soya-bean meal and ground oats was offered. It had a crude protein (CP; nitrogen $\times 6.25)$ content of $190 \mathrm{~g} / \mathrm{kg}$ and a metabolizable energy (ME) of $10.8 \mathrm{MJ} / \mathrm{kg}$. For the first $21 \mathrm{~d}$ of pregnancy the animals received a restricted quantity of the diet $(120 \mathrm{~g} / \mathrm{d})$ but for the final $10 \mathrm{~d}$ of pregnancy the diet was offered ad lib. A high-protein diet was offered throughout lactation (Table 1). This diet had been found to support high levels of milk output in the lactating doe (G. G. Partridge, unpublished results).

\section{Animals}

Twelve crossbred does were used. These were the progeny of New Zealand White bucks and Californian does, kept under minimal disease conditions at the Rowett Institute. All does had previously completed two or three lactations.

\section{Procedures}

After parturition and initial suckling each doe was removed to a metabolism cage and was allocated at random to one of four feeding levels, $240,280,320$ or $360 \mathrm{~g} / \mathrm{d}$. The litter size of each doe was adjusted to eight pups on the day of birth by culling or cross-fostering. The doe was removed from the metabolism cage once daily to feed her pups for a single 3-4 min suckling period, following the normal behaviour of the lactating rabbit. Milk yields were calculated by weighing the doe and her pups separately both before and after suckling. No creep feed was offered to the pups throughout the $32 \mathrm{~d}$ lactation. The experiment was replicated three times.

In replicates 1 and 2 each doe was placed, in its metabolism cage, inside a small direct calorimeter (Pullar, 1969) on days 4, 5, 12,13,20, 21, 28 and 29 of its lactation (day $1=$ the day of parturition). In the third replicate each doe was placed in the calorimeter on days $4,12,20$ and 28 and its litter (inside a nestbox) on days 5, 13, 21 and 29. The results of the energy exchanges of the litters will be described elsewhere. 
Urine and faeces were collected separately each day and pooled during each $8 \mathrm{~d}$ period, the $\mathrm{N}$ and energy contents of both urine and faeces being determined in each of the four periods. Food intakes were recorded daily; spillage and residues were fed back when animals were outside the calorimeter. At the end of each 8-d period any residues were weighed and animals commenced the new period on their appropriate feeding level, i.e. $240,280,320$ or $360 \mathrm{~g} / \mathrm{d}$. Throughout the experiment all does and their litters were maintained at $16^{\circ}$, on a $12 \mathrm{~h}$ light $-12 \mathrm{~h}$ dark cycle.

\section{Milk composition}

The effects of feeding level and stage of lactation on the composition of does' milk were determined by hand-milking another group of twelve does (four feeding levels $\times$ three replicates) on days $4,12,20$ and 28 of lactation. Earlier work had shown that it was impossible to collect milk from does without disturbing their subsequent milk secretion on the day of collection. Consequently, if the main group of does had been sampled their recorded milk output would have been in error.

Samples of 15-20 $\mathrm{g}$ were obtained from two anterior mammary glands after the injection of 1 i.u. oxytocin. The samples were analysed for total solids, $\mathrm{N}$, fat and heat of combustion.

\section{Analytical methods}

Details of the analytical methods used for $\mathbf{N}$ estimation in excreta are given by Spreadbury (1978). After freeze-drying and grinding the faecal samples, fur was removed by sieving them through a fine mesh screen $(500 \mu \mathrm{m})$. (Fur was being lost and ingested during grooming, particularly during the first week of lactation, and it was removed to avoid the possibility of underestimating $\mathbf{N}$ digestibility.)

The heat of combustion of diets, freeze-dried faeces, urine and milk were determined in an adiabatic bomb calorimeter. Samples of urine and milk were freeze-dried on a polythene sheet of known energy value and their gross energy values were obtained by difference.

The fat and total solids contents of rabbits' milk were estimated by the methods described by Ling (1949).

\section{Statistical treatment of results}

Standard split plot and regression analyses were used throughout.

\section{RESULTS}

\section{Milk composition}

There was no effect of level of feeding on the energy or $\mathrm{N}$ contents of the milk. However, composition changed significantly with the stage of lactation (Table 2), as reported in an earlier study (Partridge \& Allan, 1982). The mean weekly values obtained were used in later calculations on the energy and $\mathrm{N}$ balances of the main group of does.

\section{DM intakes}

In Fig. 1 the mean daily DM intakes achieved are compared with the DM offered in each of the four periods. The low and variable intakes observed during the first 8-d period reflect the gradual rise in DM intakes of the does in the days following parturition. As lactation progressed the differences in intake between the four feeding level groups became more distinct, with mean daily DM intakes being at their maximum in the final period of lactation. It is of interest to note that, although the animals which were offered $360 \mathrm{~g}$ food daily refused part of this, they none the less ate more than those on the lower levels of feeding who also refused a portion of the food offered. 
Table 2. Milk composition $(\mathrm{g} / \mathrm{kg}$ ) changes over periods $1-4$ of lactation

(Each value represents the mean of twelve observations, differences between feeding levels being non-significant. Measurements were made around the mid-point of each 8-d period)

\begin{tabular}{lccccc}
\hline \hline Period of lactation $\ldots$ & 1 & 2 & 3 & 4 & $\begin{array}{c}\text { SED of } \\
\text { difference }\end{array}$ \\
\hline Total solids & 312 & 331 & 309 & 360 & $8 \cdot 4^{* * *}$ \\
Nitrogen & $17 \cdot 9$ & $18 \cdot 0$ & $16 \cdot 8$ & $19 \cdot 9$ & $0 \cdot 5^{* * *}$ \\
Fat & 161 & 170 & 145 & 186 & $9 \cdot 3^{* *}$ \\
Gross energy $(\mathrm{MJ} / \mathrm{kg})$ & $8 \cdot 42$ & $9 \cdot 61$ & $8 \cdot 41$ & $10 \cdot 25$ & $0 \cdot 4^{* * *}$ \\
\hline \hline
\end{tabular}

** $P<0.01, * * * P<0.001$.

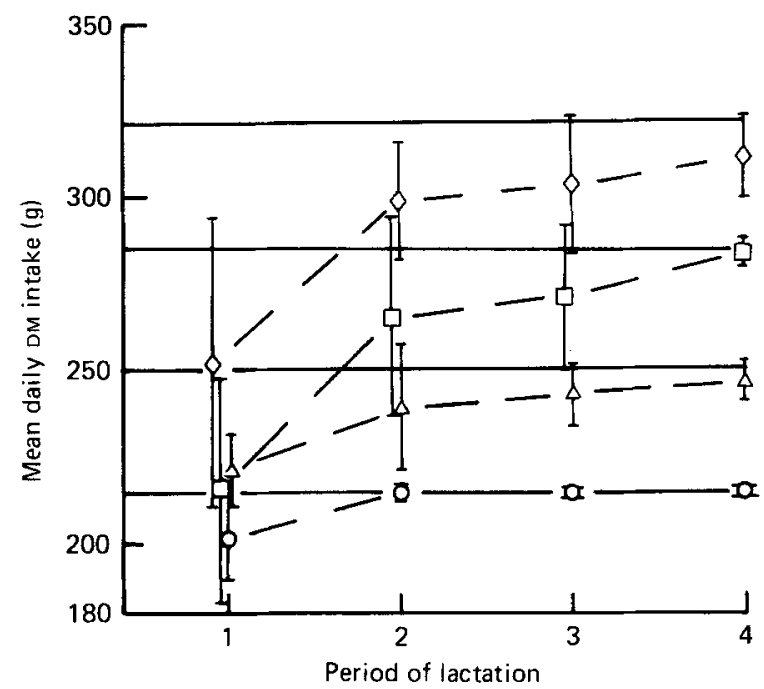

Fig. 1. The daily DM intake of does on feeding levels $1(\mathrm{O}, 240 \mathrm{~g} / \mathrm{d}), 2(\triangle, 280 \mathrm{~g} / \mathrm{d}), 3(\square, 320 \mathrm{~g} / \mathrm{d})$ and $4(\diamond, 360 \mathrm{~g} / \mathrm{d})$ over the course of lactation. Each period of lactation consisted of $8 \mathrm{~d}$. All values are means with their standard errors represented by vertical bars.

\section{Milk production}

Doe weight-loss during suckling was found to be a more reliable indicator of milk yield than pup weight gain, which was often subject to errors due to urination by the pups prior to weighing. Table 3 shows the milk yields in each period at the four levels of feed intake. Milk production on feeding levels 1,2 and $3(240,280$ and $320 \mathrm{~g} / \mathrm{d}$ respectively) was not significantly different, but yields of does on feeding level $4(360 \mathrm{~g} / \mathrm{d})$ were significantly higher than other groups, notably in the third period, at the peak of the rabbits' lactation curve.

\section{Energy and $N$ digestibility}

There was no effect of feeding level on the ME of the diet, the overall mean of forty-eight observations being 13.61 (SE 0.40) MJ/kg DM. Similarly, the level of feeding had no effect on the apparent digestibility of $\mathrm{N}$ in the diet, the overall mean being $0 \cdot 813$ (SE $0 \cdot 030$ ).

\section{Doe body-weight change}

There were no significant differences between the body-weights of does on the four feeding 
Table 3. The mean daily milk production $(\mathrm{g})$ of does over four successive 8-d periods at four levels of feeding

\begin{tabular}{|c|c|c|c|c|c|}
\hline $\begin{array}{l}\text { Level of feeding } \\
\text { (g/d offered) ... }\end{array}$ & $\begin{array}{c}1 \\
(240)\end{array}$ & $\begin{array}{c}2 \\
(280)\end{array}$ & $\begin{array}{c}3 \\
(320)\end{array}$ & $\begin{array}{c}4 \\
(360)\end{array}$ & $\begin{array}{l}\text { SE of difference } \\
\text { between means } \\
\text { in body of table }\end{array}$ \\
\hline \multicolumn{6}{|l|}{$\begin{array}{l}\text { Period of } \\
\text { lactation }\end{array}$} \\
\hline 1 & 141 & 148 & 132 & 179 & \multirow{4}{*}{$21 \cdot 3$} \\
\hline 2 & 210 & 227 & 216 & 268 & \\
\hline 3 & 242 & 248 & 242 & $319\}$ & \\
\hline 4 & 182 & 193 & 176 & 2441 & \\
\hline Overall mean & 195 & 204 & 193 & 254 & $12 \cdot 3$ \\
\hline
\end{tabular}

Table 4. Mean body-weights of does $(\mathrm{kg})$ on the four feeding levels over the course of lactation

\begin{tabular}{|c|c|c|c|c|c|}
\hline Period post partum (d) ... & 1 & 8 & 16 & 24 & 31 \\
\hline \multicolumn{6}{|l|}{ Feeding level $\dagger$} \\
\hline I & 3.83 & 4.04 & 4.08 & 3.98 & 3.94 \\
\hline 2 & 3.73 & $4 \cdot 03$ & $4 \cdot 01$ & 3.97 & 3.92 \\
\hline 3 & 3.79 & 4.08 & $4 \cdot 10$ & 4.06 & $4 \cdot 10$ \\
\hline 4 & 4.03 & $4 \cdot 20$ & $4 \cdot 21$ & $4 \cdot 10$ & $4 \cdot 10$ \\
\hline $\begin{array}{l}\text { SED between means } \\
\text { in body of table }\end{array}$ & & & 0.11 & & \\
\hline
\end{tabular}

$\uparrow$ For details, see Table 3.

levels over the course of lactation (Table 4). Peak body-weights corresponded to the period of maximum milk production on all treatments, on approximately day 20 post partum.

\section{Energy exchanges in the calorimeter}

An initial examination of the results from replicates 1 and 2 revealed that there was a very high correlation $(r 0.98)$ between heat losses on successive days in the calorimeter at constant DM intake. In subsequent calculations, therefore, a mean value was taken for an animal's DM intake, heat loss and milk output in replicates 1 and 2 . In replicate 3 the does were only in the calorimeter for $1 \mathrm{~d}$ in each 8 - $\mathrm{d}$ period so this single value was used (see Material and Methods).

Does appeared to be in positive energy balance on all feeding levels in the first period of lactation but thereafter all animals mobilized body tissue to support their milk energy outputs (Table 5). The effects of ME intake on milk energy output, milk $\mathbf{N}$ output, heat loss and body energy retention were determined by regression analysis (Table 6) with body-weight being used as a covariate. In all these relationships there were no significant differences between slopes for the four periods of lactation but the intercept terms were significantly different $(P<0.001)$. Weight alone had a significant effect on all the dependent variables shown in Table 6 but in each case its effect was less than that of ME intake alone.

The effects of $N$ digested on apparent body $N$ retention and milk $N$ output were examined (Table 7). Body-weight had significant effects on both these factors but these effects were small compared with that of $\mathrm{N}$ digested. 
Table 5. The daily energy balance of does at four levels of feeding over the course of lactation (each period consisting of $8 d$ )

(Values are means of three observations measured at the mid-point of each consecutive 8-d period)

\begin{tabular}{|c|c|c|c|c|c|}
\hline $\begin{array}{l}\text { Level of } \\
\text { feeding }\end{array}$ & $\begin{array}{l}\text { Period of } \\
\text { lactation }\end{array}$ & $\begin{array}{c}\text { ME } \\
\text { intake } \\
(\mathbf{k J})\end{array}$ & $\begin{array}{l}\text { Heat } \\
\text { loss } \\
(\mathbf{k J})\end{array}$ & $\begin{array}{c}\text { Milk } \\
\text { energy } \\
\text { loss } \\
(\mathbf{k J})\end{array}$ & $\begin{array}{c}\text { Apparent } \\
\text { body energy } \\
\text { retention }(+ \\
\text { or loss }(-) \\
(\mathbf{k J})\end{array}$ \\
\hline \multirow[t]{2}{*}{$\begin{array}{c}1 \\
(240 \mathrm{~g} / \mathrm{d})\end{array}$} & $\begin{array}{l}1 \\
2 \\
3 \\
4\end{array}$ & $\begin{array}{l}2947 \\
2980 \\
3012 \\
2986\end{array}$ & $\begin{array}{l}1661 \\
1643 \\
1639 \\
1598\end{array}$ & $\begin{array}{l}1204 \\
1963 \\
2079 \\
1844\end{array}$ & $\begin{array}{l}+82 \\
-626 \\
-706 \\
-456\end{array}$ \\
\hline & Overall & 2981 & 1635 & 1773 & -427 \\
\hline \multirow[t]{2}{*}{$(280 \mathrm{~g} / \mathrm{d})$} & $\begin{array}{l}1 \\
2 \\
3 \\
4\end{array}$ & $\begin{array}{l}2990 \\
3340 \\
3374 \\
3397\end{array}$ & $\begin{array}{l}1605 \\
1745 \\
1727 \\
1721\end{array}$ & $\begin{array}{l}1319 \\
2241 \\
2170 \\
2053\end{array}$ & $\begin{array}{l}+66 \\
-646 \\
-523 \\
-377\end{array}$ \\
\hline & Overall & 3275 & 1700 & 1946 & -370 \\
\hline \multirow[t]{2}{*}{$\begin{array}{c}3 \\
(320 \mathrm{~g} / \mathrm{d})\end{array}$} & $\begin{array}{l}1 \\
2 \\
3 \\
4\end{array}$ & $\begin{array}{l}3009 \\
3492 \\
3805 \\
3779\end{array}$ & $\begin{array}{l}1611 \\
1853 \\
1841 \\
1841\end{array}$ & $\begin{array}{r}931 \\
2084 \\
2102 \\
1892\end{array}$ & $\begin{array}{l}+467 \\
-445 \\
-138 \\
+46\end{array}$ \\
\hline & Overall & 3467 & 1775 & 1703 & -11 \\
\hline \multirow[t]{2}{*}{$\begin{array}{c}4 \\
(360 \mathrm{~g} / \mathrm{d})\end{array}$} & $\begin{array}{l}1 \\
2 \\
3 \\
4\end{array}$ & $\begin{array}{l}3405 \\
3869 \\
4214 \\
4235\end{array}$ & $\begin{array}{l}1777 \\
1946 \\
1989 \\
1948\end{array}$ & $\begin{array}{l}1431 \\
2656 \\
2858 \\
2643\end{array}$ & $\begin{array}{l}+197 \\
-733 \\
-633 \\
-356\end{array}$ \\
\hline & Overall & 3931 & 1915 & 2397 & -381 \\
\hline
\end{tabular}

ME, metabolizable energy.

Table 6. Summary of regression equations for the effects of metabolizable energy (ME) intake and body-weight (W) on milk energy output (Milk E), milk Noutput (Milk $N$ ), heat loss (Heat) and body energy retention (Body ER)

(ME intake, milk energy, heat loss and body energy are expressed in $\mathrm{kJ} / \mathrm{d}$, body-weight in $\mathrm{g}$, and milk $\mathrm{N}$ output in $\mathrm{g} / \mathrm{d}$; values in parentheses are standard errors)

\begin{tabular}{|c|c|c|c|c|}
\hline Period of lactation ... & 1 & 2 & 3 & 4 \\
\hline $\begin{array}{c}\text { Milk } \mathrm{E}=0.384 \mathrm{~W}+0.520 \mathrm{ME} \text { intake } \\
(\mathrm{SE} 0.215)(\mathrm{SE} 0.108)\end{array}$ & -1929 & -1115 & -1112 & -1279 \\
\hline $\begin{array}{c}\text { Milk } \mathrm{N}=0.0008 \mathrm{~W}+0.001 \mathrm{ME} \text { intake } \\
(\mathrm{SE} 0.0004)(\mathrm{SE} 0.0002)\end{array}$ & $-3 \cdot 65$ & $-2 \cdot 44$ & $-2 \cdot 18$ & $-2 \cdot 69$ \\
\hline $\begin{array}{l}\text { Heat }=0.182 \mathrm{~W}+0.249 \mathrm{ME} \text { intake } \\
(\mathrm{SE} 0.032)(\mathrm{SE} 0.016)\end{array}$ & +158 & +196 & +155 & +145 \\
\hline $\begin{aligned} \text { Body } E R= & -0.566 \mathrm{~W}+0.231 \mathrm{ME} \text { intake } \\
& (\mathrm{SE} 0.220)(\mathrm{SE} 0.111)\end{aligned}$ & +1772 & +920 & +958 & +1133 \\
\hline
\end{tabular}


Table 7. The effect of nitrogen digested $N(N$ Dig) and body-weight $(W)$ on apparent body $N$ retention (App NR) and milk $N$ output (Milk $N$ )

(Body-weight expressed in $\mathrm{g}$, all other measurements in $\mathrm{g} / \mathrm{d}$ )

\begin{tabular}{|c|c|c|c|c|}
\hline Period of lactation & 1 & 2 & 3 & 4 \\
\hline $\begin{array}{c}\text { App NR }=0.0000 \mathrm{~W}+0.663 \mathrm{~N} \text { Dig } \\
(\text { SE } 0.0001)(\text { SE } 0.026)\end{array}$ & -0.61 & -0.67 & -0.51 & $-0 \cdot 58$ \\
\hline $\begin{array}{c}\text { Milk } \mathrm{N}=0.0008 \mathrm{~W}+0.480 \mathrm{~N} \text { Dig } \\
(\mathrm{SE} 0.00038)(\mathrm{SE} 0.081)\end{array}$ & -0.70 & +0.44 & +0.69 & $+0 \cdot 13$ \\
\hline
\end{tabular}

Multiple regression analyses were performed in order to estimate the apparent efficiency with which the does' body tissues were utilized for milk production, using only the values from the periods when the animals were in negative energy balance (i.e. excluding early lactation, period 1). When ME intake was the dependent variable and milk energy output (Milk E) and body energy retention (Body ER) were the independent variables, there was no significant difference between the slopes for each period but the intercept terms were significantly different $(P<0 \cdot 05)$. Overall the relationship was described by the equation:

$$
\begin{array}{cccc}
\text { Period of lactation ... } & 2 & 3 & 4 \\
\text { ME intake }=1.336 \text { Milk E + 1.256 Body ER } & +417 & +397 & +392 \\
(\mathrm{SE} \mathrm{0.036)} \quad(\mathrm{SE} 0 \cdot 060) &
\end{array}
$$

where ME intake, Milk E and Body ER are expressed in $\mathrm{kJ} / \mathrm{kg}$ body-weight (W) ${ }^{0.75}$.

To examine the efficiency more directly milk energy output was used as the dependent variable in an additional computation using the same data. Again the slopes for each period were combinable but the intercept terms were significantly different $(P<0.05)$, the overall equation being:

$$
\begin{gathered}
\begin{array}{cccc}
\text { Period of lactation ... } & 2 & 3 & 4 \\
\text { Milk E }=0.735 \text { ME intake }-0.938 \text { Body ER } & -296 & -280 & -276 \\
\text { (SE 0.020) } & \text { (SE 0.039) }
\end{array}
\end{gathered}
$$

where ME intake, Milk E and Body ER are expressed in $\mathrm{kJ} / \mathrm{kg} \mathrm{W}^{0.75}$.

The values for animals in positive energy balance were considered too scant to attempt to estimate the efficiency of use of ME for body-tissue accretion.

\section{DISCUSSION}

The changes in milk composition observed over the course of lactation in the present study confirm the observations of Cowie (1969) and of Partridge \& Allan (1982). Fat concentration in the milk was higher than that reported by Lebas (1971) who used machine milking, rather than the manual milking technique used in the other studies. Dietary differences, however, are superimposed on these comparisons and clearly more information is needed on the effects of methods of milk collection on apparent composition.

There was a distinct increase in milk output of the does in response to increasing dietary energy intakes with the exception of two does in treatment group 3. These animals achieved similar DM intakes to their treatment group counterparts but produced notably less milk, 
resulting in the low mean value reported in Table 3 . This seems to indicate that individual does respond variably in the way they partition nutrients from the same ration, presumably because of different genetic potentials for milk production and because of varying endocrinological factors. This is exemplified in its extreme when dairy cows are compared with their 'beef-producing' counterparts (Flatt \& Moe, 1970).

Body-weight change was a poor indicator of body-tissue mobilization in the doe. The balance results indicated that all does were mobilizing body tissue for milk production by the second period of lactation (i.e. around day 11 post partum, Table 5) and in general continued to do so for the remainder of lactation. Over the same time period does were apparently increasing in body-weight up to a peak around day 20 post partum (Table 4). Clearly, factors such as gut fill and body-tissue hydration were contributing to this discrepancy between the two measurements.

The estimates of the efficiency of utilization of ME and body-tissue energy for milk production may be compared with equivalent values for the lactating dairy cow. Flatt $e t$ al. (1967) investigated the relationship between ME intake $\left(\mathrm{kJ} / \mathrm{kg} \mathrm{W}^{0.75}\right.$ per d) and energy balance ( $\mathrm{EB}$, milk energy + body tissue energy; $\mathrm{kJ} / \mathrm{kg} \mathrm{W}^{\mathbf{0} \cdot 75}$ ) by linear regression from seventy-two pairs of observations on lactating dairy cows. They described their observations by the equation:

$$
\begin{aligned}
& \mathrm{EB}=0.66 \mathrm{ME} \text { intake }-390 . \\
& \quad(\mathrm{SE} 0.018)
\end{aligned}
$$

In the present study the comparable relationship was described by the equation:

$$
\begin{aligned}
& \mathrm{EB}=0.76 \mathrm{ME} \text { intake }-322 . \\
& (\mathrm{SE} 0 \cdot 016)
\end{aligned}
$$

The higher efficiency found in the doe is presumably because the nonruminant animal is able to utilize directly more of its dietary ME than the ruminant. The contribution of volatile fatty acids (VFA) to the rabbit's ME requirements is relatively small: Hoover \& Heitmann (1972) estimated that VFA provide approximately $90 \mathrm{~kJ} / \mathrm{d}$, while Parker (1976) suggested a higher contribution, 269 and $194 \mathrm{~kJ} / \mathrm{d}$ for animals on restricted $(100 \mathrm{~g} / \mathrm{d})$ and ad lib. $(80-200 \mathrm{~g} / \mathrm{d})$ feeding respectively. At the high intake $(360 \mathrm{~g} / \mathrm{d})$ in the present study, therefore, the daily energy contribution from VFA could be of the order of $100-150 \mathrm{~kJ} / \mathrm{d}$ which is only approximately $3 \%$ of the doe's daily ME intake. In contrast, however, many studies have shown the importance of changes in the molar proportions of VFA to milk yield, milk composition and energy utilization by lactating cows (Flatt \& Moe, 1970).

Flatt \& Moe (1970), using partial regression analysis, found the relationship between milk energy output (Milk E), ME intake and body energy retention (Body ER) was described by the equation:

$$
\text { Milk } \mathrm{E}=0.632 \mathrm{ME} \text { intake }-0.84 \text { Body ER }-333 \text {, }
$$

$$
\text { (SE 0.01) (SE 0.02) }
$$

where all variables are expressed in $\mathrm{kJ} / \mathrm{kg} \mathrm{W}^{0} \cdot 75$.

An identical calculation using the values from the animals in negative energy balance in the present study resulted in the following equation (see p. 513):

$$
\begin{gathered}
\text { Milk E }=0.735 \text { ME intake }-0.938 \text { Body ER }-284 . \\
(\text { SE 0.02) }
\end{gathered}
$$

These coefficients indicate that mobilized body tissue is used more efficiently for milk production in the lactating doe than it is in the dairy cow $(94 \% v .84 \%)$. This difference is probably enhanced by the fact that throughout the present study the does were all in positive $\mathrm{N}$ balance and that consequently this efficiency value relates purely to fat mobilization. 
From eqns (1) and (4) it is possible to estimate the apparent maintenance requirement of the does for comparison with published values. At zero energy balance, ME for maintenance from eqn (1) is $392-417$ (mean 402 ) $\mathrm{kJ} / \mathrm{kg} \mathrm{W}^{0.75}$ per $\mathrm{d}$ and from eqn (4) is $424 \mathrm{~kJ} / \mathrm{kg} \mathrm{W} \mathrm{W}^{0.75}$ per d. A comparable value from the results of Eriksson (1952) is $385 \mathrm{~kJ} / \mathrm{kg} \mathrm{W}^{0.75}$ per d. Clearly, differences in breed types used in these studies could account for observed differences in maintenance requirements and, in addition, Eriksson's (1952) animals were non-productive and of smaller mature body size $(3 \mathrm{~kg})$.

The ME of the diet used in the present study $(12.1 \mathrm{MJ} / \mathrm{kg}$ air dry diet) was higher than that found in most commercially produced diets (typically $9.0 \mathrm{MJ} / \mathrm{kg}$ air dry diet; Lang, 1981). Clearly it would be of interest to extend investigations of this nature to examine the effects of ME intake on the efficiency of food energy utilization for milk production over a range of ME concentrations. The level of protein in the diet would also be of importance in such studies. Our animals were in positive $\mathrm{N}$ balance throughout lactation with, on average, $333 \mathrm{mg} \mathrm{N}$ being retained $/ \mathrm{kg} \mathrm{W}^{0.75}$ per $\mathrm{d}$. Studies in the ruminant have clearly shown that intake of protein in excess of requirements for maintenance and lactation results in a decrease in energy balance due to the increased metabolic cost of excreting excess $\mathrm{N}$ as urea (Tyrrell et al. 1970).

There is a marked discrepancy in the literature with respect to practical recommendations for the energy requirements of the doe at peak lactation. Total ME requirements have been variously estimated as three times maintenance (Clarke et al. 1977), four times maintenance (Davidson \& Spreadbury, 1975) or more (Costa-Batllori, 1973). Our results indicate that a doe yielding $300 \mathrm{~g}$ milk/d at peak lactation in week 3 (Table 3) would have a daily ME requirement for milk production of $0.300 \times 8.41 \times 100 / 74=3.41 \mathrm{MJ}$, assuming no translocation of body energy to milk energy. The total requirement of a $4 \mathrm{~kg}$ doe would therefore be approximately $4.57 \mathrm{MJ}(3.41 \mathrm{MJ}+\mathrm{a}$ maintenance requirement of $1.16 \mathrm{MJ}$, see above). On a standard commercial ration $(9 \mathrm{MJ} / \mathrm{kg})$ intakes in excess of $500 \mathrm{~g} / \mathrm{d}$ would be needed to satisfy this energy requirement from the ME of the feed alone, and such levels of intake would be clearly unattainable in practice. In contrast, offering ad lib. a high-energy diet, such as that used in the present study, may enable animals to meet these requirements from dietary sources alone.

The authors would like to acknowledge the technical assistance of Mrs Susan Allan. Chemical analyses were performed by the analytical section of Applied Nutrition, notably by Mrs Lorraine McDonald. We would like to thank Mr Alan Brewer for advice on statistical treatment of the results.

\section{REFERENCES}

Clarke, H. E., Coates, M. E., Eva, J. K., Ford, D. J., Milner, C. K., O'Donoghue, P. N., Scott, P. P. \& Ward, R. J. (1977). Lab. Anim. 11, 1.

Costa-Batllori, P. (1973). Proc. Int. Conv. Rabbit Prod. ERBA, Italy, 209.

Cowie, A. T. (1969). J. Endocr. 44, 437.

Davidson, J. \& Spreadbury, D. (1975). Proc. Nutr. Soc. 34, 75.

Eriksson, S. (1952). Kungl. Lanbruksh. Ann. 19, 7.

Flatt, W. P. \& Moe, P. W. (1970). In Lactation, p. 341 [I. R. Falconer, editor]. London: Butterworths.

Flatt, W. P., Moe, P. W., Munson, A. W. \& Cooper, T. (1967). Publs Eur. Assoc. Anim. Prod. no. 12, p. 235.

Hoover, W. H. \& Heitmann, R. N. (1972). J. Nutr. 102, 375.

Lang, J. (1981). Nutr. Abs. Rev. Ser. B, 51, 197, 287.

Lebas, F. (1971). Ann. Zootech. 20, 185.

Ling, E. R. (1949). Textbook of Dairy Chemistry, vol. 2. London: Chapman and Hall.

Parker, D. S. (1976). Br. J. Nutr. 36, 61.

Partridge, G. G. \& Allan, S. (1982). Anim. Prod. 35, 145. 
Pullar, J. D. (1969). In International Encyclopaedia of Food and Nutrition, vol. 17, Nutrition of Animals of Agricultural Importance, part I, p. 471 [D. P. Cuthbertson, editor]. Oxford: Pergamon Press.

Spreadbury, D. (1978). Br. J. Nutr. 39, 601.

Tyrrell, H. F., Moe, P. W. \& Flatt, W. P. (1970). Publs Eur. Ass. Anim. Prod. no. 13, p. 69.

Van Es, A. J. H. \& Nijkamp, H. J. (1967). Publs Eur. Ass. Anim. Prod. no. 12, p. 209. 